University of South Florida

DIGITAL COMMONS

Digital Commons @ University of

@ UNIVERSITY OF SOUTH FLORIDA

South Florida

$4-9-2004$

\title{
Discovering the Source of Gatsby's Greatness: Nick's Eulogy of a "Great" Kierkegaardian Knight
}

Jaime' L. Sanders

University of South Florida

Follow this and additional works at: https://digitalcommons.usf.edu/etd

Part of the American Studies Commons

\section{Scholar Commons Citation}

Sanders, Jaime' L., "Discovering the Source of Gatsby's Greatness: Nick's Eulogy of a "Great" Kierkegaardian Knight" (2004). USF Tampa Graduate Theses and Dissertations.

https://digitalcommons.usf.edu/etd/1234

This Thesis is brought to you for free and open access by the USF Graduate Theses and Dissertations at Digital Commons @ University of South Florida. It has been accepted for inclusion in USF Tampa Graduate Theses and Dissertations by an authorized administrator of Digital Commons @ University of South Florida. For more information, please contact digitalcommons@usf.edu. 
Discovering the Source of Gatsby's Greatness:

Nick’s Eulogy of a "Great" Kierkegaardian Knight

by

Jaime’ L. Sanders

A thesis submitted in partial fulfillment of the requirements for the degree of Master of Arts Department of English College of Arts and Sciences University of South Florida

Co-Major Professor: Phillip Sipiora, Ph.D. Co-Major Professor: Lawrence Broer, Ph.D.

Laura Runge, Ph.D.

Date of Approval:

April 9, 2004

Keywords: fitzgerald, narrator, caraway, faith, existentialism

(C) Copyright 2004, Jaime’ L. Sanders 


\section{Acknowledgments}

I would like to thank Dr. Lawrence Broer for his insights as a professor, a mentor, and a guide. I am forever in your debt for my teaching position since I would not have further pursued it on my own. Dr. Laura Runge, I thank you again one thousand times over for the opportunities you have given me, the wealth of knowledge you have proved to be, and the encouragement I sometimes needed to feel that I would eventually "get it." And of course, Dr. Phillip Sipiora, who first rekindled my love for literature and film and contaminated my mind with eager enthusiasm. To all of you, your passion and excitement is contagious and I can only hope that those you teach catch the bug. I thank you for all of your encouragement, advice, and guidance throughout my Graduate Studies. 
Table of Contents
Abstract
Introduction
Discovering the Source of Gatsby's Greatness:
Nick's Eulogy of a “Great” Kierkegaardian Knight
References
Bibliography 


\title{
Discovering the Source of Gatsby's Greatness: \\ Nick’s Eulogy of a "Great” Kierkegaardian Knight \\ Jaime L. Sanders
}

\begin{abstract}
Although F. Scott Fitzgerald's The Great Gatsby has received extensive critical attention since the middle of the century, there remains an unaddressed and unanswered question that demands further exploration: what makes Gatsby "great?" It seems that the source of Gatsby's greatness, for narrator Nick Carraway, is that Gatsby has a quality that sets him apart from others: it is not a "flabby impressionability," but a "heightened sensitivity to the promises of life" and "an extraordinary gift for hope" that Nick has never seen before, nor does he expect to see again (6). I contend that what Nick sees as Gatsby's belief and hope in the possibilities of life are embodied in what Kierkegaard discusses in his works Either/Or and Fear and Trembling as choosing to live an ethical existence free from the pain of the material world. Gatsby makes this choice (of living ethically) when the young James Gatz chooses to become Jay Gatsby and free himself from the pain of losing Daisy. Through this choice, according to Kierkegaard, the ethical individual is inducted into the knighthood as a knight of infinity. If the knight makes one more movement, he becomes a knight of faith who believes, "Nevertheless I have faith that I will get her- that is, by virtue of the absurd, by virtue of the fact that for God all things are possible" (Fear and Trembling 46). Gatsby is a "son of God" that "sprang
\end{abstract}


from his Platonic conception of himself"; he is a Kierkegaardian knight who has chosen an ethical existence; he is a knight who has the ability to look impossibility in the eye and still have faith to the point of absurdity, even if a reunion with his love (Daisy) is not possible. This is Gatsby's “extraordinary gift for hope," which Kierkegaard attributes to "the only great one," the knight of faith. Thus, Nick's narrative is not only a canonization of his "great" knight, but an imaginative recollection that traces the movements of his knight, Gatsby, down the same path Kierkegaard imaginatively follows and observes his great knight of faith in Fear and Trembling. 


\section{Introduction}

One of F. Scott Fitzgerald's concerns in his own life continually breaks through in his personal as well as his literary writing; that is, of Fitzgerald's need to resolve his public and private selves. Fitzgerald, himself, struggled with lost love, an overbearing, then institutionalized wife, Zelda, his own outrageous, alcohol-induced episodes, regret for those episodes, money, social status, literary status, and satisfaction with his own works. In his later years, Fitzgerald pined for his lost youth, although his adulthood was plagued, as his young life was, with a feeling of social and personal inadequacy (Lehan). His social inadequacy was acutely felt with the loss of Fitzgerald's first love, Ginevra King, who, according to Fitzgerald, became the subject of his novel The Great Gatsby. “"The whole idea of Gatsby,' Fitzgerald said, 'is the unfairness of a poor young man not being able to marry a girl with money. This theme comes up again and again because I lived it", (Lehan 72). Not only did Fitzgerald live this theme, but illustrates through Gatsby, a way to escape the pain of lost love and crushed expectations. According to Richard Lehan,

When Fitzgerald lost Genevra, he came to believe that such yearning was an end in itself; he believed in the need to preserve a romantic state of mind where the imagination and the will are arrested - in a state of suspension - by an idealized concept of beauty and love. The loss creates an eternal striving, and hope keeps the world beautifully alive. (72) 
Fitzgerald's need to "preserve a romantic state of mind" sets him apart from the disillusionment, hopelessness, and despair characteristic of the modern condition of the Jazz Age. He sees imagination as a necessity because it is a way out of the crisis of modernity, a way to resolve the despair that accompanies reality and move beyond it to the ideal. What is beyond reality, for Fitzgerald, is not only what is conceived and preserved by the imagination, but is a need for spirituality in a spiritually decentered age. Fitzgerald's view that the imagination can resolve the crisis between one's own public and private selves, the reality of the world verses what we can dream, is not only the central thematic device in Gatsby, but is a model for living spiritually in a age when wealth and material goods replaced conventional religion:

Fitzgerald exposes the absence of an authentic orthodoxy in American Capitalist democratic ideology through his use of the tycoon protagonist in The Great Gatsby... Without being explicitly Christian, the absent orthodoxy is certainly religious in its function, which is to define a way of living morally in the world by providing the theoretical bridge between the abstract (ideal, spiritual) and the material planes. (Bizzell

Similarly, R.W. Stallman argues in his article "Gatsby and the Hole in Time" that "Gatsby transcends reality and time... He resides only particularly at West Egg, for he exists simultaneously on two planes: the mythic or the impersonal and the human, the immaterial and the real" (56). Not only was rectifying these two planes of existence Fitzgerald's ultimate concern, he made it Jay Gatsby's concern, as well. Both Fitzgerald 
and Gatsby seem to "preserve a romantic state of mind" in order to escape the painful reality that they have lost the women they love. Nick Carraway recognizes this "romantic readiness" in Gatsby which seems to set Gatsby apart from other men; in part, what makes Gatsby "great" for Nick. Yet, this theme is not exclusively Fitzgerald's; nearly a century earlier, Soren Kierkegaard not only discusses the planes of existence Fitzgerald was so concerned with, but illustrates his philosophy through a young lad who falls in love with a princess, imaginatively following this young man in his ascent to greatness.

In his works Either/Or and Fear and Trembling/Repetition, Kierkegaard discusses the differing states of existence humans have to choose from and traces the path of a young man who chooses a higher form of existence to escape the pain of living in the material world. The source of this young man's pain is his inability to marry the princess he loves. An examination of Kierkegaard's philosophy not only reveals many similarities between Fitzgerald's narrative and Kierkegaard's philosophy, but seems to provide a key for deciphering Nick's narrative, as well as understanding Nick's view of Gatsby's nature and actions.

Although there have been no explicit connections made between Kierkegaard's theology and Fitzgerald's personal philosophy, it is possible that Fitzgerald encountered Kierkegaard's works as early as his years at The Newman School, a Catholic boarding school he attended from 1911-1913. It was at The Newman School during the fall of 1912 that Fitzgerald met friend and mentor Father Cyril Sigourney Webster Fay who was a converted Catholic minister, admired scholar, and religious poet whom Fitzgerald remained friends with and corresponded with until Father Faye's death in 1919 (Bruccoli 
33-4, 93). It is likely that Father Faye encountered the works of Catholic theologian Soren Kierkegaard as soon as they were accessible in English due to his interest in theology and scholarship, and since Fitzgerald studied with Father Faye with the intention of entering the priesthood, it is possible Father Faye introduced Fitzgerald to Kierkegaard's theology. According to Kierkegaard scholars Hong and Hong, "The Swedes were the first to recognize Kierkegaard's importance, followed by the Germans and the French. The English-speaking world knew virtually nothing about Kierkegaard until 1908, when a book of selections were rendered into English.” Shortly thereafter, between 1914 and 1925, several critical articles and book reviews appeared in English, which discussed and critiqued Kierkegaard's theology. J.G. Robert's article "Soren Kierkegaard" appeared in the Modern Language Review in 1914 and articles by David F. Swenson appeared from 1916-1921. Swenson's 1916 article “The Anti-Intellectualism of Kierkegaard" appeared in The Philosophical Review filled with praise for Kierkegaard's ability to present his philosophy in accessible language and through understandable illustrations. In this article Swenson also discusses some of the specifics of Kierkegaard's philosophy from his work Either/Or; namely, Kierkegaard's classifications of human's existence as a constant tension between his/her aesthetic (external) and ethical (internal) existence, merely different terms for Fitzgerald's concept of the need to resolve one's private and public existence.

Although Kierkegaard's and Fitzgerald's treatment of the subject of the formation of personality and the self seem to find common ground in the character Jay Gatsby, it is unclear when Fitzgerald was exposed to Kierkegaard's theology. If Fitzgerald did not 
encounter Kierkegaard through his time at the Newman School or through discussions with Father Faye, it is still possible that his time at Princeton introduced him to this theology; or Fitzgerald could have encountered Kierkegaard's works as late as 1923; the same year he began writing The Great Gatsby, L. M. Hollander translated and published "Selections from the Writings of Kierkegaard," which was followed by several book reviews appearing in journals in 1924-5. Hollander's translations contained selections from Kierkegaard's Either/Or and Fear and Trembling/Repetition, the same works I will argue provide the philosophical framework for The Great Gatsby. Although an explicit connection between Fitzgerald and Kierkegaard can not be made historically, there is an implicit connection between Fitzgerald's story of a poor young man who is unable to marry a rich girl and Kierkegaard's illustration of his philosophy of existence through a story of a young lad who falls in love with an unattainable princess (Fear and Trembling). My investigation of Fitzgerald's, and more importantly, Nick's narrative centers around Kierkegaard's notion of the greatness of this young lad and thus, the underlying sentiments surrounding Gatsby's greatness in Nick's eyes. 


\section{Discovering the Source of Gatsby's Greatness: \\ Nick’s Eulogy of a "Great” Kierkegaardian Knight}

Although F. Scott Fitzgerald's The Great Gatsby has received extensive critical attention since the middle of the century, there remains an unanswered question that demands further exploration: what makes Jay Gatsby “great?" In order to begin to answer this question, we must explore Nick Carraway's narrative view--a view which has been the center of much critical debate. Nick's claims that he is "inclined to reserve all judgments" (5) and that he is "one of the few honest people" he has ever known (64) have been called into question by numerous scholars (Town, Donaldson, Nehaus, Mallios, Elmore). They all seem to agree that Nick has a highly romantic view of Gatsby, and it is this excessive romanticizing of Gatsby and the events in the narrative, along with the contradictions between his actual narrative and his claims to objectivity and honesty, that render Nick an unreliable narrator. Yet, it seems that it is Nick's romantic view of Gatsby that codifies the events depicted in the narrative and provides the reader with the opportunity to discover the source of Gatsby's greatness. Caren Town suggests that "[w]ords may lack the power to express objective truth, but Nick believes in their power authentically to embody emotion in metaphor and in his power therefore to be true to his story, an account of strictly emotional truth" (Town 497). Since I believe it is in how Nick sees Gatsby that the truth of the narrative is revealed, we must focus not only on Nick's narrative view, but reach into Nick's narrative consciousness to discover why, for 
Nick, Gatsby is "great."

If we look beyond the surface of the narrative contradictions, it appears that the inconsistencies in Nick's narrative are the result of Nick's own growing awareness of himself and of human nature; specifically, Gatsby's nature. How Nick initially views Gatsby is much different than how he sees and feels about Gatsby at the end of the narrative; yet the narrative is retrospective. A.E. Elmore suggests that regardless of retrospection, Nick's narrative is the process by which he comes to understand Gatsby and thus solidify his view of Gatsby. Nick's narrative view is in constant flux because "whatever is learned is presented to the reader through the medium of Nick's consciousness and that that consciousness reflects, in the course of the novel, a growing understanding of the nature of the human experience it observes" (Elmore 130). When one takes Elmore's assumption into consideration, Nick's contradictions become less a question of integrity and reliability, and more a record of the process of his growth from ignorance to complete awareness and understanding of what he thinks to be Gatsby's true nature.

Nick narrative traces the path of his consciousness from immediately before he met Gatsby, until the moment he writes the narrative, two years after Gatsby's death. We see Nick's "unaffected scorn" (6) and his "feeling of defiance, of scornful solidarity between Gatsby and me against them all” (173) grow into admiration and loyalty. This growth is evident at the beginning of the narrative when Nick offers us an initial retrospective summation of his feelings toward Gatsby as exempt from Nick's usual reaction to men like Gatsby. 
Only Gatsby, the man who gives his name to this book, was exempt from my reaction - Gatsby who represented everything for which I have an unaffected scorn... there was something gorgeous about him... it was an extraordinary gift for hope, a romantic readiness... which it is not likely I shall ever find again. No-Gatsby turned out all right at the end...

(Fitzgerald 6)

Although Nick does not exalt Gatsby greatness here, Nick's view of Gatsby has changed from scorn to "all right." David Parker argues this is because

Only slowly, and in spite of himself, does Nick come to appreciate the human and moral reality of Gatsby, to appreciate that "inexhaustible variety of life" is operative at the moral as well as at the aesthetic level.

It is because Nick's understanding of Gatsby is a gradual process that his initial views towards Gatsby change after Nick contemplates Gatsby's life and death; and although this gives the appearance of unreliability, it seems Nick is attempting to faithfully record his impressions and experiences as they originally happened. Nick originally sees Gatsby as an "ambiguous central icon" (Mallios 365) - an object of his scorn, a man whose life and past are the center of much speculation-yet the "truth" the narrative records is the process by which Nick comes to understand and admire Gatsby. It is through careful attention to this process that we can discover what Nick projects onto Gatsby that makes him "great" in Nick's eyes.

The part of the process that we must first consider is Nick's purpose in writing the 
narrative. It is important to note that Nick does not create his narrative simply to record his own growth; his purpose is much more noble. His narrative serves as a eulogy of a man who, in Nick's view, is greatly misunderstood. It becomes Nick's task to redeem Gatsby from the speculation that plagues Gatsby in life, and swarms around him in his death (6). Nick writes:

Most of those reports were a nightmare - grotesque, circumstantial, eager and untrue... I found myself on Gatsby's side, and alone... it grew upon me that I was responsible, because no one else was interested-interested, I mean, with that intense personal interest to which everyone has some vague right at the end. (Fitzgerald 171-2)

Two years after Gatsby's death, Nick still feels responsible in some way; responsible for clearing the misunderstandings that surround Gatsby. Because Nick comes sees Gatsby as a tragic hero in need of redemption, this becomes Nick's first and foremost purpose in writing the narrative: to redeem his tragic hero, Gatsby. This narrative act of redemption is described by Soren Kierkegaard as the poet's duty to the hero. In "Eulogy on Abraham," Kierkegaard writes:

The poet or orator can do nothing that the hero does; he can only admire, love, and delight in him... He is recollection's genius. He can do nothing but bring to mind what has been done, can do nothing but admire what has been done... so that all may admire the hero as he does... This is his occupation, his humble task; this is his faithful service in the house of the hero... Therefore, no one who was great will be forgotten, and even 
though it takes time, even though a cloud of misunderstanding takes away the hero, his lover [the poet] will nevertheless come, and the longer the passage of time, the more faithfully he adheres to him... (Fear and Trembling 15-16)

Nick is “recollection's genius" who, two years after Gatsby's death, takes occupation as a writer to tell Gatsby's story. Since “a cloud of misunderstanding” surrounds Gatsby's death, it becomes Nick's task to remove Gatsby from the "foul dust" which surrounds him - Gatsby neither killed Myrtle with his car, nor was he having an affair with her as many rumors supposed (Fitzgerald 6). This is Nick's "faithful service" to Gatsby: "that no one who was great will be forgotten" (Fear and Trembling 15). And although Nick's role as narrator is important to understanding Nick's narrative view, it is actually Nick's first description of Gatsby that provides an initial key to the specific reasons why Nick sees Gatsby as "great."

In the opening pages of the narrative, Nick offers us an initial description of Gatsby's nature, as well as his understanding of, and disdain for, what he has discovered in the hearts of men. Gatsby is "exempt from his reaction"; exempt because Gatsby embodies something that separates him from those who are the objects of Nick's scorn (6). Nick writes:

When I came back from the East last autumn I felt that I wanted the world to be in uniform and at a sort of moral attention forever; I wanted no more riotous excursions with privileged glimpses into the human heart. Only Gatsby, the man who gives his name to this book, was 
exempt from my reaction--Gatsby who represented everything for which I have an unaffected scorn. If personality is an unbroken series of successful gestures, then there was something gorgeous about him, some heightened sensitivity to the promises of life, as if he were related to one of those intricate machines that register earthquakes ten thousand miles away. This responsiveness had nothing to do with that flabby impressionability which is dignified under the name of the 'creative temperament' - it was an extraordinary gift for hope, a romantic readiness such as I have never found in any other person and which it is not likely I shall ever find again. No-Gatsby turned out all right at the end; it is what preyed on Gatsby, what foul dust floated in the wake of his dreams that temporarily closed out my interest in the abortive sorrows and short-winded elations of men. (Fitzgerald 6-7)

For Nick, one thing that sets Gatsby apart from others is what is in Gatsby's heart. It is not a "flabby impressionability," but a "heightened sensitivity" to life that Nick has never seen before, nor does he expect to see again (6). Yet, it is unclear from this passage why the characteristics Nick attributes to Gatsby separate him from all other men. It seems Nick provides a clue in his statement that "if personality is an unbroken series of successful gestures, then there was something gorgeous about him"; yet it does not seem that personality is the true marker of what is in one's heart (6). But, for Kierkegaard, the formation of the personality in an individual has everything to do with one's true nature, with what is in one's heart. 
Kierkegaard's discussion of an individual's choice to shape their own personality offers us an insight into Nick's view of Gatsby. According to Kierkegaard, the formation of one's personality is a choice that involves a movement, or a gesture, as Nick puts it. If one chooses properly and successfully makes the movement, as Nick intimates Gatsby has, then he has successfully chosen to live what Kierkegaard calls an "ethical existence" (Either/Or 178). Yet, Gatsby does not seem to live "ethically" according to the standard understanding of the term "ethical": he is a bootlegger with less than reputable associates; a man with no past who came out of nowhere and bought a mansion in West Egg; a man whose profession and source of wealth are a matter of public speculation. In short, what Gatsby represents—-bourgeois greed, absurd materialism, and wealth — are normally the object of Nick's “unaffected scorn”; yet Gatsby is exempt from his reaction. He is exempt "even though his life may be described as unethical," because living ethically for Kierkegaard, is a heightened state of existence (Either/Or 178). It is a state of existence that Nick describes as Gatsby's "heightened sensitivity to life," which separates Gatsby from other men.

According to Kierkegaard, there are two distinct natures of humans with two distinct forms of existence to choose from. Each individual has a choice to live either an aesthetic existence, ruled by exteriority, or an ethical existence, free from earthly constraints. One who chooses to live ethically shapes his/her personality through this choice. The ethical individual resolves the pain of existence through this choice, which frees him/her from the constraints of laws and social customs that causes the aesthetes great despair; he/she follows instinct or desire over what society deems appropriate or 
inappropriate. This is why the ethical individual appears to be unethical: he/she is neither concerned with, nor subscribes to, the man-made conventions of society. Yet the key to living an ethical existence, according to Kierkegaard, is that one must choose to live ethically. When faced with the choice, many choose wrong and continue to live what Kierkegaard describes as an aesthetic existence ruled by exteriority; the aesthetes "are enslaved and lack transparency" (Either/Or 183). In short, the aesthetes who do not choose correctly remain bound to the ideas and conventions of the material world; they allow themselves to be socially determined. Gatsby, on the other hand, chooses to live ethically, or at least we can see that Nick thinks Gatsby has made this choice; yet, since living an ethical existence is a choice according to Kierkegaard, we must discover when and how Nick believes Gatsby came to make this choice.

It is not only important to discover when Nick believes Gatsby makes the choice to live an ethical existence, but to understand why and how Gatsby came to make this choice. According to Kierkegaard, the choice is made to free one from the pain of existence, yet we must determine what Nick sees as the source of Gatsby's pain. Nick's narrative reveals that Gatsby, in his youth, suffered greatly from a broken-heart; his pain is rooted in lost love. When Gatsby, still the young James Gatz, returns from military service to find his love, Daisy, on her honeymoon, he is devastated. He visits Daisy's house, wanders the streets they walked, and visits the out of the way places they went together. Young Gatz is heart-broken and still penniless, bound to earthly love and promises, "his heart... in a constant and turbulent riot" (Fitzgerald 105). According to Kierkegaard "it appears that every aesthetic attitude toward life is despair... Now let us 
see why they despaired; because they discovered that what they had built their life on was transitory?" (Either/Or 186). It seems that this is the realization the young Gatz comes to when he returns to find Daisy married: that Daisy's love for him was only love of the fleeting moment. Although Nick is not a witness to the young Gatz's realization, Nick projects and imagines how Gatsby must have felt: "He stretched out his hand desperately as if to snatch only a wisp of air, to save a fragment of the spot that she had made lovely for him. But it was all going by too fast now for his blurred eyes and he knew that he had lost that part of it, the freshest and the best, forever" (Fitzgerald 161). Nick believes that Gatz grieves for what he has lost, and what he cannot get back: Daisy, off on her honeymoon, is gone forever. Regardless of the fact that Nick's imagination projects this onto Gatz, we can see that the realization of this loss is real and devastates Gatz since his life from this point on becomes an effort focused on getting Daisy back. The glimpses we get of Gatsby's life after Daisy is gone reflect the constant unrest and pain that accompanies the realization that life and love are transitory. Nick expresses both the physical and spiritual unrest he feels Gatsby experiences as a result of this realization: Each night he added to the pattern of his fancies until drowsiness closed down upon some vivid scene with an oblivious embrace. For a while these reveries provided an outlet for his imagination; they were a satisfactory hint of the unreality of reality, a promise that the rock of the world was founded securely on a fairy's wing. (Fitzgerald 105)

According to Nick, the young James Gatz, disheartened and wallowing in despair, aimlessly wanders the shores of Lake Superior for the next year, working just enough to 
provide bodily sustenance. Gatz's “instinct” then leads him to St. Olaf’s Lutheran college, but he only stays a few weeks since the place leaves him feeling "dismayed at its ferocious indifference to the drums of his destiny, to destiny itself" (Fitzgerald 105). The realization that he may have a destiny besides his current wandering and despair leads him back to the shores of Lake Superior, "still searching for something to do" that will release him from his aesthetic existence, which is enveloped in a pervasive despair. According to Kierkegaard, "it appears that every aesthetic attitude toward life is despair, and that everyone who lives aesthetically is in despair, whether he knows it or not. But if one knows this... then a higher form of existence is an urgent requirement" (Either/Or 186). So it is on the day Gatz returns to Lake Superior, "searching for something to do" to resolve his grief that Gatz chooses a higher form of existence: he chooses an ethical existence. Kierkegaard explains this "choice" as choosing the self, which Nick seems to see in James Gatz's choice to become Jay Gatsby.

James Gatz - that was really, or at least legally, his name. He had changed it at the age of seventeen and at the specific moment that witnessed the beginning of his career - then he saw Dan Cody's yacht drop anchor over the most insidious flat on Lake Superior. It was James Gatz who had been loafing along the beach that afternoon in a torn green jersey and a pair of canvas pants, but it was already Jay Gatsby who borrowed a row-boat, pulled out to the Tuolomee and informed Cody that a wind might catch him and break him up in half an hour. (Fitzgerald 104) 
Although Nick is not a witness to Gatsby's day on the beach, he seems to have his own understanding of Gatz's transformation into Gatsby. He seems to see young Gatz choosing the ethical to transcend the pain of the material world since he is penniless, has lost Daisy, and is "searching for something to do" to relieve his pain. If he chooses correctly, he frees himself from the constraints and despair of the material world. Kierkegaard describes this choice as such:

... the one who is correctly situated... chooses himself, not in a finite sense, for then this "self" would become a finite thing along with other finite things, but in an absolute sense; and yet he chooses himself and not another. This self he chooses is infinitely concrete, for it is himself, and yet it is absolutely distinct from his earlier self, for he has chosen the absolute. This self has not existed before, for it came to be through the choice, and yet it did exist, for it was indeed "himself." (Either/Or 203-4) Whether young Gatz's choice to change his name is actually the choosing of an ethical existence is questionable, yet what is important is that Nick sees this choice not only as "an urgent requirement" for the grieving, love-sick Gatz, but as the turning point in Gatz's life. Not only does "the specific moment" of Gatz choice mark the beginning of Jay Gatsby's career, it also marks the specific moment, according to Kierkegaard when the heavens part, as it were, and the I chooses itself, or more correctly, it receives itself ... Then the personality receives the stroke of knighthood which ennobles it for an eternity. He does not become something other 
than what he was before, but he becomes himself; the consciousness unites, and he is himself. (Either/Or 181)

This man, for Nick, has successfully made the gesture of choosing an ethical existence: he becomes one with himself, is thus inducted into knighthood, and becomes a "son of God" as Kierkegaard describes of Abraham. Nick projects a similar view onto Gatsby:

I suppose he'd had the name ready for a long time, even then. His parents were shiftless and unsuccessful farm people - his imagination had never really accepted them as his parents at all. The truth was that Jay Gatsby, of West Egg, Long Island, sprang from his Platonic conception of himself. He was a son of God - a phrase which, if it means anything, means just that - and he must be about His Father's Business, the service of a vast, vulgar and meretricious beauty. So he invented just the sort of Jay Gatsby that a seventeen year old boy would be likely to invent, and to this conception he was faithful to the end. (Fitzgerald 104)

In Nick's view, Gatsby's choice to live ethically is a conscious choice that "sprang from his Platonic conception of himself" as a "son of God." For Kierkegaard, the man who chooses himself, unites with his conception of himself, and becomes a knight of infinity, believes that all things are possible, since for God all is possible. The knight perceives himself as a son of God, which Nick projects as Gatsby's belief, as well. According to Kierkegaard, when one makes the choice to resign himself to himself, he makes the movement of infinite resignation that makes his soul eternal; he becomes a son of God. Nick describes this choice as "an unbroken series of successful gestures," gestures he 
believes Gatsby has successfully made through infinite resignation. Yet Nick's description denotes that a series of gestures, not just one, is involved in the formation of the personality of the ethical individual; thus he believes that Gatsby makes this movement more than once. In Kierkegaard's formulation, Nick is correct. After induction into the knighthood, the knight must continually make the movements of choice, of resignation, in order to remain free from the pain he originally resigned himself to.

Since the knight still lives in the material world, he is by no means exempt from feeling the angst or pain of existence, thus he must continually resign himself to this pain in order to transcend the pain: this is infinite resignation. Yet, Kierkegaard notes that there is a higher state of existence that only the knight of infinity can choose: he can choose, as Abraham does, to be a knight of faith. Kierkegaard writes: "Infinite resignation is the last stage before faith, so that anyone who has not made this movement does not have faith" (Fear and Trembling 45). This faith, which Nick describes as Gatsby's "heightened sensitivity to the promises of life" and his "extraordinary gift for hope," frees the knight from the earthly pain of existence since for the knight of faith all things are possible; "that is, by virtue of the absurd, by virtue of the fact that for God all things are possible" (Fear and Trembling 46). Richard Lehan in The Great Gatsby: The Limits of Wonder agrees that what makes Gatsby a "son of God" is his belief in infinite possibilities: "Gatsby sees the world in a wondrous way when he becomes a son of God... Without the sense of eternal possibility, Gatsby will no longer be his own god, will no longer be Gatsby" (40). Yet it seems for Nick, Gatsby is more than a just a "son of god" with infinite possibilities in life; he sees Gatsby as one of Kierkegaard's knights, 
and like Kierkegaard, believes the knight of faith is "great, the only great one" because he has faith in infinite possibilities, even in the face of impossibility. It is this faith in impossibility, according to Kierkegaard, that makes meeting a knight of faith one of the greatest of all things. To meet a knight is to have the opportunity to observe greatness.

Nick seems to share Kierkegaard's sentiment that to meet a knight is one of the greatest of all things since neither Nick, nor Kierkegaard have any interest in "privileged glimpses into the human heart" of the aesthetes, nor in the "abortive sorrows and short winded-elations of men" (Fitzgerald 6-7). These are the recipients of Nick's "unaffected scorn" and it seems Kierkegaard's beliefs are commensurable with Nick's. In "Problemata 'Preliminary Expectoration," Kierkegaard distinguishes between the aesthetes and the ethical knights, a distinction Nick himself suggests throughout the narrative as the difference between those who are the object of his scorn, and Gatsby. Kierkegaard writes:

Generally, people travel around the world to see rivers and mountains, new stars, colorful birds, freakish fish, preposterous races of mankind; they indulge in the brutish stupor that gnaws at life and thinks it has seen something. That does not occupy me. But if I knew where a knight of faith lived, I would travel on foot to him, for this marvel occupies me absolutely. I would not leave him for a second, I would watch him every minute to see how he made the movements; I would consider myself taken care of for life and would divide my time between watching him and practicing myself, and thus spend all my time in admiring him. (Fear and 


\section{Trembling 38)}

For Nick, the aesthetes who "gnaw at life" are people like Daisy and Tom who "nibble at the edge of stale ideas" and believe they are privy to a view of life others are not (Fitzgerald 25). They believe this because their wealth and materialism allow them the opportunities to travel and see many things, which superficially give them a sense of selfimportance. We can see this during Nick's first visit with Daisy, Tom, and Jordan at the beginning of the narrative. Daisy tells Nick, "I've been everywhere and seen everything and done everything... Sophisticated—God, I'm sophisticated!” (Fitzgerald 22). Nick thinks:

The instant her voice broke off, ceasing to compel my attention, my belief, I felt the basic insincerity of what she had said... she looked at me with an absolute smirk on her lovely face as if she had asserted her membership in a rather distinguished secret society to which she and Tom belonged. (Fitzgerald 22)

According to David Lynn, Daisy's comments do not compel Nick because “Daisy lacks any meaningful integrity between self and gesture" (179). Nick sees both Daisy and Tom as belonging to a meaningless, bourgeois society that lives aesthetically: a society of "short-winded elations" in which he has no interest (Fitzgerald 7). They, like other aesthetes, are insincere and full of self-importance: they "smashed up things and creatures and then retreated back into their money or their vast carelessness or whatever it was that kept them together, and let other people clean up the mess they had made" (Fitzgerald 188). Thus, Nick, uninterested in Daisy and Tom's society, immediately 
leaves for home in West Egg and catches his first glimpse of Gatsby; unbeknownst to him, his first glimpse of a knight.

[W]hen I reached my estate at West Egg I ran the car under its shed and sat for a while on an abandoned grass roller in the yard. The wind had blown off, leaving a loud bright night with wings beating in the trees and a persistent organ sound as the full bellows of the earth blew the frogs full of life... I saw that I was not alone - fifty feet away a figure had emerged from the shadow of my neighbor's mansion and was standing with his hands in his pockets regarding the silver pepper of the stars. Something in his leisurely movements and the secure position of his feet upon the lawn suggested that it was Mr. Gatsby himself, come out to determine what share was his of our local heavens.

I decided to call to him... But I didn't call to him for he gave a sudden intimation that he was content to be alone--he stretched out his arms toward the dark water in a curious way, and far as I was from him I

could have sworn he was trembling. Involuntarily I glanced seaward—and distinguished nothing except a single green light, minute and far away, that might have been the end of a dock. (Fitzgerald 25-6)

According to Kierkegaard, Nick is unaware of the meaning of Gatsby's movements and trembling because the knight of infinity "is continually making the movement of infinity, but he does it with such precision and assurance that he continually gets finitude out of it, and no one ever suspects anything else" (Fear and Trembling 40). Thus, Nick 
misrecognizes Gatsby's leisurely and secure movements as bourgeois pretension, as determining "what share was his of our local heavens" (25). Yet what is telling is Nick's observation of Gatsby's trembling, a trembling that Kierkegaard attributes to resigning oneself to the pain of existence; a characteristic of a knight of infinity. Kierkegaard writes:

Most people live completely absorbed in worldly joys and sorrows; they are bench warmers who do not take part in the dance. The knights of infinity are ballet dancers and have elevation. They make the upward movement and come down again, and this, too, is not an unhappy diversion and is not unlovely to see. But every time they come down, they are unable to assume the posture immediately, they waver for a moment, and this wavering shows that they are aliens in the world. (Fear and

\section{Trembling 41)}

Just as Nick is initially unaware of the significance of Gatsby's movements toward the green light, he is also initially unaware of many other minute observations he makes of Gatsby throughout the narrative; it is only as Nick's understanding grows throughout the initial events, and as "recollection's genius" that Nick comes to attribute a higher meaning to Gatsby's movements.

Nick observes Gatsby continually making the movements of resignation but, as Kierkegaard notes, he never suspects anything. Even after Jordan reveals to Nick that the green light in the distance belongs to Daisy and he realizes that "it had not been merely the stars to which he [Gatsby] had aspired on that June night. He came alive to me, 
delivered suddenly from the womb of his purposeless splendor"; yet, even with the knowledge of Gatsby's purpose, Nick is still unable to recognize Gatsby's movements of resignation upon initial observations (Fitzgerald 83). Instead, Nick describes Gatsby’s continual movements, his unbalanced "wavering," as a form of restlessness. Nick writes: He [Gatsby] was balancing himself on the dashboard of his car with that resourcefulness of movement that is so peculiarly American—that comes, I suppose, with the absence of lifting work or rigid sitting in youth and, even more, with the formless grace of our nervous, sporadic games. This quality was continually breaking through his punctilious manner in the shape of restlessness. He was never quite still; there was always a tapping foot somewhere or the impatient opening and closing of a hand. (Fitzgerald 68)

The knight, according to Kierkegaard, "at every moment is making the movement of infinity... even the most skillful of knights cannot hide this wavering" (Fear and Trembling 40-1). Yet Kierkegaard admits he has never met a knight. If he did, he would, like Nick does, spend all of his time in trying to decipher the nature of the knight's movements.

Although Kierkegaard admits he himself has never met a knight, his imagined meeting offers us another insight into Nick's view of Gatsby's nature. Kierkegaard writes:

I may very well imagine him. Here he is. The acquaintance is made, I am introduced to him. The instant I first lay eyes on him, I set him apart at 
once; I jump back, clap my hands, and say half aloud, "Good Lord, is this the man, is this really the one - he looks just like a tax collector!" But this is indeed the one. I move a little closer to him, watch his slightest movement to see if it reveals a bit of heterogeneous optical telegraphy for the infinite, a glance, a facial expression, a gesture, a sadness, a smile that would betray the infinite in its heterogeneity with the finite. No! I examine his figure from top to toe to see if that may not be a crack though which the infinite would peek. No! He is solid all the way through. His stance? It is vigorous, belongs entirely to finitude; no spruced-up burgher walking out to Fresberg on a Sunday afternoon treads the earth more solidly. He belongs entirely to the world; no bourgeois philistine could belong to it more. Nothing is detectable of that distant and aristocratic nature by which the knight of the infinite is recognized. (Fear and Trembling 38-9)

The main difference in the demeanors of the knight of infinity and the knight of faith, in Kierkegaard's formulation, is that "they who carry the treasure of faith are likely to disappoint for externally they have a striking resemblance to bourgeois philistinism" (Fear and Trembling 38). Gatsby has this resemblance which Nick notes at the beginning of his narrative as the source of his "unaffected scorn." Yet, we must remember that Gatsby is "exempt" from this reaction: exempt because he only appears, as the knight appears on the surface, to embody the characteristics of bourgeois philistinism. The knight of infinity, on the other hand, seems to possess a "distant and aristocratic nature" that Gatsby, from a poor family without a past, "an elegant young roughneck" does not 
seem to embody. Kierkegaard's description of a knight of faith appearing as a bourgeois philistine seem to reflect Nick's initial impressions of Gatsby on the lawn "come out to determine what share was his of our local heavens" as well as Nick's impression of Gatsby on their first meeting.

On first meeting a knight, Kierkegaard would, as Nick does, examine the suspected knight to discern if he/she makes the movements that typify a knight of infinity or a knight of faith. The following is the occasion of Gatsby and Nick's first meeting:

"I'm Gatsby," he said suddenly.

"What!" I exclaimed. "Oh, I beg your pardon."

“I thought you knew old sport. I'm afraid I'm not a very good host."

He smiled understandingly - much more than understandingly. It was one of those rare smiles with a quality of eternal reassurance in it that you may come across four or five times in life. It faced - or seemed to face - the whole external world for an instant, and then concentrated on you with an irresistible prejudice in your favor. It understood you just so far as you wanted to be understood, believed in you as you would like to believe in yourself and assured you that it had precisely the impression of you that, at your best, you hoped to convey. Precisely at that point it vanished - and I was looking at an elegant young rough-neck, a year or two over thirty, whose elaborate formality of speech just missed being absurd. (Fitzgerald 52-3). 
If Nick, like Kierkegaard, is looking for incongruities in the knight's nature, he seems to find one is Gatsby's smile; yet it is only for an instant before it vanishes. It is in this moment that Nick recognizes the "eternal reassurance" in Gatsby's smile as belonging to the infinite. When it vanishes, Nick is left staring at "an elegant young roughneck," a bourgeois philistine whose manner of speech is almost absurd. Richard Lehan agrees that "[b]eneath the elaborate, albeit gaudy, elegance of Gatsby looms James Gatz, the original 'roughneck' that Gatsby spends so much energy trying to conceal” (59). There is nothing in Lehan's assumption that suggests that Gatsby's manner reflects the "distant and aristocratic nature" that Kierkegaard attributes to a knight of infinity. Instead, Gatsby seems to be "picking his words with care" giving the impression that he, and his wealth, do not derive from nobility, thus resembling a knight of faith. Nick, like Kierkegaard, can "see nothing sinister about him" since he appears solid, as one who belongs to finitude: he appears to belong to this world; appears to be "just a man named Gatsby" (Fitzgerald 53-4).

Although at first glance Gatsby appears to be just a man, Nick comes to understand the central ruling force that drives Gatsby's movements; that is, Gatsby's love for Daisy. Thus, at the heart of Nick's narrative is the story of Gatsby's and Daisy's tragic love affair, an affair by which Gatsby's position in the knighthood can be fully realized. Nick sees Gatz's loss of Daisy as the catalyst for his creation of Gatsby's, and thus the catalyst for Gatz and Gatsby's movements of infinite resignation and faith. Kierkegaard notes that he has seen many attempt resignation, but has never seen a successful movement, himself. So, Kierkegaard provides an illustration of infinite 
resignation to show how one makes the movement correctly and successfully, a movement Nick seems to believe Gatsby has made.

Kierkegaard illustrates infinite resignation through a story of a young man who falls in love with a princess, a story that seems to follow Nick's imaginative recollections of Gatsby's love for Daisy. Kierkegaard writes:

A young lad falls in love with a princess, and this love is the entire substance of his life, and yet the relation is such that it cannot possibly be realized, cannot possibly be translated from ideality into reality. Of course, the slaves of the finite, the frogs in the swamps of life, scream: That kind of love is foolishness... Let them go on croaking in the swamp. The knight of infinite resignation does not do any such thing; he does not give up the love, not for all the glories of the world. He is no fool. First of all, he assures himself that it actually is the substance of his life, and his soul is too healthy and too proud to waste the least of it in an intoxication. (Kierkegaard 41-2)

We know from several different passages in the narrative, that Gatsby, although a bootlegger, does not consume alcohol. Actually, Nick notes that "women used to rub champagne into his [Gatsby's] hair; for himself he formed the habit of letting liquor alone" (Fitzgerald 107). The knight avoids intoxication because he would rather allow his love to "palpitate in every nerve" (Fear and Trembling 42). Instead of wasting away in intoxication, the knight, as well as Gatsby focuses on that love for the princess and embraces it infinitely. Even though Daisy is married, Gatsby does not let his love go; 
"that type of love is foolishness" (Fear and Trembling 41). Kierkegaard believes that the one who does this, who resigns himself to this love in the face of impossibility, is great. But because this love is an impossibility, the knight must continually resign himself to this love to relieve his pain. He is in pain because the reality is that attaining his desire (i.e., attaining the princess) is a matter of infinite hope; thus infinite resignation is a selfperpetuating cycle. The knight must resign himself to the pain of existence, which yields the pain of impossibility, which warrants the movement be made again and again. Thus it is called "infinite" resignation; the knight is always in the process of resigning. Kierkegaard further illustrates the knight's infinite movements in terms that recall Gatsby's parties and provide a further insight into Nick's vision of Gatsby's resignation. Having totally absorbed this love and immersed himself in it, he does not lack the courage to attempt and to risk everything. He examines the condition of his life, he convenes the swift thoughts that obey his every hint, like well-trained doves, he flourishes his staff, and they scatter in all directions. But now when they all come back, all of them like messengers of grief, and explain that it is an impossibility, he becomes very quiet, he dismisses them, he becomes solitary, and then he undertakes the movement... the knight will then have the power to concentrate the whole substance of his life and the meaning of actuality into one single desire... the knight will have the power to concentrate the conclusion of all his thinking into one act of consciousness. (Fear and Trembling 42-3) 
This passage illuminates Gatsby's summer parties at his West Egg mansion. During Gatsby's parties, Nick observes that Gatsby remains quiet, alone, and most times, hidden. This seems strange for a host of such a large gathering; yet it is not until Jordan reveals Gatsby's reason for throwing the parties that, for Nick, Gatsby is "delivered from the womb of his purposeless splendor" (Fitzgerald 83). Jordan tells Nick that

Gatsby bought that house so that Daisy would be just across the bay... I think he half expected her to wander into one of his parties, some night... but she never did. Then he began asking people casually if they knew her, and I was the first one he found... he says he's read a Chicago paper for years just on the chance of catching a glimpse of Daisy's name.

(Fitzgerald 83-4)

Gatsby has concentrated the whole substance of his life - his accumulation of wealth, his big house just across the water from Daisy, his parties, hoping she will eventually happen to show - on one singular desire: his princess, Daisy. Kierkegaard describes this as the knight's "power to concentrate the conclusion of all his thinking into one act of consciousness" (Fear and Trembling 43). Thus, everything that Gatsby has "achieved" has been focused on his one desire, Daisy. Yet since he has not yet attained his desire (i.e., the princess), the knight, Gatsby, must continually make the movements of resignation. After the "messengers of grief"- the party-goers - come and go without a word of Daisy, Gatsby is always left alone, in solitude, to once again undertake the movement of resignation: to again resign himself to the pain of losing Daisy, as well as the pain of not being reunited with her . During one of Gatsby's parties, Nick observes 
"Gatsby, standing alone on the marble steps and looking from one group to another with approving eyes" (Fitzgerald 54); yet shortly thereafter the party breaks up and Nick observes "[a] sudden emptiness seemed to flow now from the windows and the great doors, endowing with complete isolation the figure of the host who stood on the porch" (Fitzgerald 60). We can look back to Gatsby's transformative day on the beach when, alone and isolated, he made the movement, as well as look to the night Nick first caught a glimpse of Gatsby alone on his lawn, motioning to the green light of Daisy's dock. Nick does not call to Gatsby on the lawn "for he gave a sudden intimation that he was content to be alone" (Fitzgerald 25-6). It seems Nick comes to believe that Gatsby is content to be alone because he is the process of resigning himself to his love for Daisy, he is meditating on the object of his love.

Gatsby continually resigns himself in order to fully concentrate every act of his consciousness on his love for Daisy. The green light at the end of her dock is his own personal beacon; a beacon to which he seems to resign himself religiously. It is Kierkegaard's belief that through infinite resignation, "[h] is love for that princess would become for him the expression of an eternal love, would assume a religious character" (Fear and Trembling 43). Yet it is actually Nick that projects his view of Gatsby's desire for Daisy as possessing a religious quality; we never even indirectly hear this from Gatsby. Nick writes:

He had intended, probably, to take what he could get and go, but now he found that he had committed himself to the following of a grail. He knew that Daisy was extraordinary but he didn't realize just how extraordinary a 
"nice" girl could be. She vanished into her rich house, into her rich, full

life, leaving Gatsby—nothing. He felt married to her, that was all.

\section{(Fitzgerald 156-7)}

Nick sees Gatsby's life since he first met Daisy as a commitment to following a grail: a quest of the unattainable Daisy. When Gatz returns from his military service to find Daisy absent from her home, he feels as if he needs to search harder for her; he feels as if he might be leaving her behind. Yet, it does not seem that Gatz quest begins until he makes the movements on the beach, according to Kierkegaard, when he realizes that love requires self-sufficiency. "He has grasped the deep secret that even in loving another person one ought to be sufficient to oneself" (Fear and Trembling 44). Thus young Gatz becomes Gatsby and begins his quest to become self-sufficient, both financially and emotionally; yet he does this with Daisy, his spiritual object, in mind.

Because Gatsby's love for Daisy transcends the temporal and becomes eternal, a grail, a spiritual center, this love no longer adheres to the constraints and assumptions of the material world, but instead passes into the realm of the ideal. Roger Lewis argues "that the love becomes more important than the object of it" (49). Nick imagines the same. "There must have been moments even that afternoon when Daisy tumbled short of his dreams - not through her own fault but because of the colossal vitality of his illusion" which had "gone beyond her, beyond everything" (Fitzgerald 101). Gatsby's illusion, in Nick's view, is that he has stored up an image of Daisy in "his ghostly heart" that is beyond what she is in reality, thus Gatsby's love has passed into the realm of abstraction, the realm of the infinite (Fitzgerald 101). 
What Gatsby's has stored in his heart is indeed the memory of Daisy in the first days of loving her. Gatsby, as Kierkegaard's knight, "keeps his love just as young as it was in the first moment; he never loses it simply because he has made the movement infinitely" (Fear and Trembling 44). Kierkegaard illustrates true resignation by presenting a scenario of what the knight would do if the princess did not make the same movements; that is, if she did not keep her love young for the knight. Kierkegaard writes: There was one who also believed that he had made the movement; but look, time passed, the princess did something else - she married, for example, a prince - and his soul lost the resilience of resignation. $\mathrm{He}$ thereby demonstrated that he had not made the movement properly, for one who has resigned infinitely is sufficient to oneself. The knight does not cancel his resignation, he keeps his love just as young as it was in the first moment; he never loses it simply because he has made the movement infinitely. What the princess does cannot disturb him. (Fear and

\section{Trembling 44-5)}

Although Daisy (the princess) marries Tom (the prince) instead of waiting for young Gatz (the knight) to return from military service, Gatsby does not renounce his love for Daisy; instead, he embraces his love for her as his single act of consciousness, keeping his love alive and young. Gatsby hopes and expects Daisy has done the same.

He wanted nothing less of Daisy than that she should go to Tom and say: "I never loved you." After she had obliterated three years with that sentence they could decide upon the more practical measures to be taken. 
One of them was that, after she was free, they were to go back to Louisville and be married from her house - just as if it were five years ago. (Fitzgerald 116)

Because the knight is not submerged in finitude, his love is as young and as strong as it was in its first moments; for the knight, as with Gatsby, it seems as if time does not exist. Once Daisy is "free" — free from Tom and free in the ethical sense — she and Gatsby can return to her house and marry as if five years had not passed. Submerged in the infinite, time_ — past, present, future — are all the same moments for the knight, for Gatsby.

The Gatsby world is wrenched into confusion and disorder by Gatsby's two-way dream - into the past and into the future... As Gatsby cannot tell past from future, the present is the same for him as one or the other - now being for him the tomorrow he hopes to possess or the yesterday he hopes to recapture. (Stallman 58)

Thus Gatsby's belief that one can repeat the past is actually a matter of infinite hope, yet even in the face of impossibility, Gatsby believes he and Daisy can start again. Nick, on the other hand, does not share this sentiment. Nick warns Gatsby:

"I wouldn't ask too much of her... You can't repeat the past."

"Can't repeat the past?" he [Gatsby] cried incredulously. "Why of course you can!”

He looked around him wildly, as if the past were lurking here in the shadow of his house, just out of reach of his hand. 
"I'm going to fix everything just the way it was before," he said, nodding determinedly. "She'll see."

He talked a lot about the past and I gathered that he wanted to recover something, some idea of himself perhaps that had gone into loving Daisy. His life had been confused and disordered since then, but if he could once return to a certain starting place and go over it all slowly, he could find out what that thing was... (Fitzgerald 116-7)

Indeed, Gatsby does want to recover something, something he lost in the act of resigning himself to his dream. Patricia Bizzell argues that "once one enters into the process of attempting to materialize the dream, the dream is already lost, because the process attempts the impossible. Gatsby can never materialize his ideal" (120), an assumption that Kierkegaard shares. Kierkegaard writes, "From the moment he [the knight of infinity] has made the movement, the princess is lost" (Fear and Trembling 44). Yet, the knight of faith, the knight of infinite hope, like Gatsby, believes that he and the princess can begin again if she is "similarly disposed" regardless of the seeming impossibility; that is, if she also makes the movement of resignation.

Gatsby not only desires to return to the time when their love was fresh and young, but as a knight of faith, he believes that this can be accomplished if Daisy is "free"; that is, if she chooses an ethical existence and is inducted into the knighthood. Kierkegaard explains,

If, however, the princess is similarly disposed, something beautiful will emerge. She will then introduce herself into the order of knighthood... 
She, too, will keep her love young and sound; she, too, will have overcome her agony, even though she does not, as the ballad says, lie by her lord's side every night... if the moment ever came that allowed them to give love its expression in time, they would be capable of beginning right where they would have begun if they had been united in the beginning. (Fear and Trembling 45)

Whether or not Daisy makes the movement of infinite resignation is important, but not as important as whether Gatsby believes he has seen Daisy make the movement. It seems Gatsby believes that Daisy has also kept her love young and they are now beginning again as if they had never been separated in the first place. It seems Gatsby believes her love to be true because he has witnessed Daisy's infinite resignation; thus his expectation that Daisy will tell Tom she never loved him. If Daisy made the movements, that means she didn't give up her love for Gatsby; instead she would have allowed her love for Gatsby to grow and become the substance of her life, which would mean she never loved Tom, as Gatsby assumes. Yet, when did Gatsby think he saw Daisy make the movement? Kierkegaard points us toward the scene where Daisy cries into Gatsby's "beautiful shirts" (Fitzgerald 98). According to Kierkegaard,

Infinite resignation is that shirt mentioned in an old legend. The thread is spun with tears, bleached with tears; the shirt is sewn in tears - but then it also gives protection better than iron or steel. The defect in the legend is that a third person can work up this linen. The secret in life is that each person must sew it himself. (Fear and Trembling 45) 
Although at first glance it seems as if Daisy cries into Gatsby's silk shirts because she realizes what she could have had if she waited for the young Gatz instead of marrying Tom: Gatsby was now rich, still handsome, and much more refined. Yet it seems Gatsby believes Daisy's tears reveal more than that: they reveal that she, too, has made her entrance into the knighthood.

Although it appears to Gatsby that Daisy resigns herself infinitely, if she has not made the movement of faith, then she still believes in the impossibility of them being together. But, if she has resigned herself to the pain of losing Gatsby in this scene, even though she falls short of a movement of faith, she has insulated herself from the pain of existence, providing protection for herself from future pain and harm, a protection that eventually shifts the blame for Myrtle's death onto Gatsby. Thus it seems Daisy makes the movement of resignation, but not the movement of faith Gatsby believes he sees. Kierkegaard explains this feigned movement as such:

If, for example, in the face of every difficulty, a young girl still remains convinced that her desire will be fulfilled, this assurance is by no means the assurance of faith... Her assurance is most captivating, and one can learn much from her, but there is one thing that cannot be learned from her-how to make movements - for her assurance does not dare, in the pain of resignation, to look impossibility in the eye. (Fear and Trembling 47) 
Gatsby seems to come to this realization - that Daisy's resignation does not include the movement of faith--the day at the Ritz when he attempts to initiate Daisy's confession to Tom that she never loved him.

"Oh, you want too much!” she cried to Gatsby. "I love you now isn't that enough? I can't help what's past." She began to sob helplessly. "I did love him once - but I loved you too."

Gatsby's eyes opened and closed.

"You loved me too?" he repeated. (Fitzgerald 140).

Gatsby, whose love is singular and who believes Daisy's love is also, for him, singular, is dumbfounded by her admission that she loved both Tom and Gatsby. At this moment, Gatsby seems to come to the realization that Daisy's resignation (that he thought he was a witness to), may not have included the movement of faith. Yet his faith, his "extraordinary gift for hope" allows him to hope and believe that Daisy has this same faith, that she was just "very excited this afternoon... And the result was she hardly knew what she was saying” (Fitzgerald 159). Thus, Gatsby does not renounce his love after this incident, nor is his dream dead as Nick suggests (Fitzgerald 142). Gatsby is still able, like the knight of faith, to look impossibility in the eye, even though it may be absurd; that it "cannot possibly be translated from ideality to reality" (Fear and Trembling 41). Gatsby tells Nick

"I don’t think she ever loved him." Gatsby turned around from a window and looked at me challengingly. "You must remember, old sport, she was very excited this afternoon. He told her those things in a way that 
frightened her - that made it look as if I was some kind of cheap sharper. And the result was she hardly knew what she was saying..."

"Of course she might have loved him, just for a minute, when they were first married — and loved me more even then, do you see?"

(Fitzgerald 159-60)

Gatsby admits that maybe Daisy did love Tom, but just for a fleeting moment, before she resigned herself infinitely to Gatsby. In the next instant, Gatsby tells Nick "In any case... it was just personal" (Fitzgerald 160). Nick is dumbfounded by Gatsby's statement and remarks: "What could you make of that, except to suspect some intensity in his conception of the affair that couldn't be measured?" (Fitzgerald 160). Indeed, Gatsby's "conception of the affair" is that Daisy's love, like his own, is infinite and singular, thus their reunion, though absurd, is a possibility. Gatsby takes this personally because "he is too proud to be willing to let the whole substance of his life turn out to have been an affair of the fleeting moment" (Fear and Trembling 44). Thus, Gatsby does not leave town after Myrtle’s murder because “[h]aving totally absorbed this love and immersed himself in it, he does not lack the courage to attempt and to risk everything" (Fear and Trembling 42). He does not leave because the knight "does not give up that love, not for all the glories in the world;" he does not leave although he is aware that he may be blamed for Myrtle's death (Fear and Trembling 42).

Nick advises Gatsby to leave town, but “He wouldn't consider it. He couldn't possibly leave Daisy until he knew what she was going to do. He was clutching at some last hope and I couldn't bear to shake him free" (Fitzgerald 155). Gatsby's last hope is 
that Daisy, too, is a knight of faith; that she will call and they will be united as if in the beginning. Regardless, Gatsby is assured by Daisy that she loves him now, thus he supposes she will call. With this assurance in mind, Gatsby decides to lie in his pool while he waits. Yet, whether Gatsby seeks the redemptive waters of his pool to resign himself infinitely to the pain of loving Daisy, or if he seeks the waters to drown himself in grief, we will never know. Since Nick is not privy to Gatsby's last thoughts, neither are we. All Nick offers us is a speculative "if" of Gatsby's last moments: if Gatsby didn't think Daisy was going to call, then he must have fallen into despair. For Kierkegaard this is also true. Since the knight has resigned himself to this love, he has "let it twist and entwine itself intricately around every ligament of his consciousness - if his love comes to grief, he will never be able to wrench himself out of it" (Fear and Trembling 42). Thus, if the knight ceases to infinitely resign himself, he will be overcome by grief; if he allows the dream to be shattered, he will fall from knighthood into aesthetic despair. It seems that Nick believes Gatsby may have sought the waters of his pool to immerse himself in grief, and to reflect on the grotesque reality of his dreams.

No telephone message arrived but the butler went without his sleep and waited for it until four o'clock - until long after there was anyone to give it to if it came. I have an idea that Gatsby himself didn't believe it would come and perhaps he no longer cared. If that was true he must have felt that he had lost the old warm world, paid a high price for living too long with a single dream. He must have looked up at an unfamiliar sky through frightening leaves and shivered as he found what a grotesque 
thing a rose is and how raw the sunlight was upon the scarcely created grass. A new world, material without being real, where poor ghosts, breathing dreams like air, drifted fortuitously about... (Fitzgerald 169)

Yet because this is wholly speculative, we are unsure if Gatsby's love has actually come to grief, or if he, in his last moments, resigns himself once again to the infinite and dies ennobled as a knight of faith.

Kierkegaard believes that each man/woman can resign themselves to the infinite, even in their last moments of life; this resignation makes the soul, and in Gatsby's case, his love, eternal. I believe that Gatsby’s "extraordinary gift for hope" and his "romantic readiness" leads him to the pool in an act of renewal; in an act of resignation, just prior to his death. Kierkegaard explains this last movement of faith as such:

In his very last moment, a person can still concentrate his whole soul in one single look to heaven, from whence come all good gifts, and this look will be understood by himself and by him whom it seeks to mean that he has been true to his love. [...] By my own strength I cannot get the least little thing that belongs to finitude, for I continually use my strength in resigning everything. By my own strength I cannot get her back again, for I use all my strength in resigning. On the other hand, by faith, says that marvelous knight, by faith you will get her by virtue of the absurd. (Fear and Trembling 49-50) 
But Gatsby is murdered by Myrtle's husband, Mr. Wilson, before he can get Daisy back. In order to get the princess, Gatsby must be the knight of faith who receives everything back that he has resigned; if he does not get the princess, it is because he is a knight of infinite resignation who has lost the princess and sees the impossibility of their future happiness; in infinite resignation the princess is lost, yet in faith, all that is resigned is returned. Yet Gatsby's tragic, untimely death ultimately alters the finite possibilities of a reunion with Daisy. This is the tragedy of Gatsby's life and death that Nick, himself, sees; that is, how close Gatsby comes to attaining his dream.

And as I sat there, brooding on the old unknown world, I thought of Gatsby's wonder when he first picked out the green light at the end of Daisy's dock. He had come a long way to this blue lawn and his dream must have seemed so close that he could hardly fail to grasp it. He did not know that it was already behind him, somewhere back in that vast obscurity beyond the city, where the dark fields of the republic rolled on under the night.

Gatsby believed in the green light, the orgastic future that year by year recedes before us. It eluded us then, but that's no matter - tomorrow we will run faster, stretch out our arms farther... And one fine morning--So we beat on, boats against the current, borne back ceaselessly into the past. (Fitzgerald 189)

It seems for Nick, Gatsby's dream always resided in the realm of impossibility, thus Gatsby's ceaseless movements of resignation are a matter of infinite hope. Gatsby's hope, 
his faith, blinds him to the reality of impossibility, thus he fails to see what is before him. Instead, Gatsby lives in the past since each time he makes the movement of resignation, he returns to the past; to the day he first resigns himself to the pain of losing Daisy. $\mathrm{He}$ must continually return to that day because it is the day that he both became himself and renounced himself. It is the beginning of his life. It is the point he must return to, over and over, to be able to start again and again. Thus Gatsby is "borne back ceaselessly into the past," that is, he experiences the day of his rebirth, again and again, through his movements of resignation. Not only can one repeat the past, as Gatsby believes, but the knight is always reaching back into the past to recover what he has lost in resigning himself: he has lost the princess there, and continually returns to find her. The "orgastic future" is the knight's infinite hope that he will, someday, have the princess; for the knight of faith receives everything back that he has lost in the act of resignation. Yet, here is the real tragedy: Gatsby is murdered before he can be reunited with Daisy.

Regardless of the fact that Gatsby is never reunited with Daisy, it seems for Nick, Gatsby is nonetheless that great knight of faith; the one who believes in the future, in infinite possibilities, in dreams. For Nick, it is the fact that Gatsby lives and dies by the code of the knighthood that makes him "great" even though he has failed to reach the impossible. Kierkegaard explains that the knight of faith is the only "great one," but "by virtue of the absurd to get everything, to get one's desire totally and completely - that is over and beyond human powers, that is a marvel" (Fear and Trembling 47-8). Gatsby is not a marvel; according to Nick "even Gatsby can happen without any particular wonder" (Fitzgerald 73). Nevertheless, it is Gatsby's "incorruptible dream" that makes him "great" 
(Fitzgerald 162). It is Gatsby's faith in the face of impossibility, "his extraordinary gift for hope" which Kierkegaard attributes to "the only great one," the knight of faith. David Minter agrees that the source of Gatsby's greatness lies in the fact that "he has dared to move beyond dreaming his dream to an attempt to live it. Because of the beauty of his dream and the heroism of his effort to move beyond it, Gatsby can be made great" (89). Likewise, for Nick, Gatsby is great because of his infinite hope that he can make the dream real, regardless of realistic impossibilities.

In the final pages of Nick's narrative, Nick makes Gatsby's failed dream a universal correlative for the failure of the American Dream. Yet, it seems that Gatsby's success or failure in achieving his dream does not figure into Nick's formulation of Gatsby's greatness; he is great because his attempt to live his dream was a great effort. It is Gatsby's faith and action that Nick aims to praise through his narrative; yet, Nick's narrative is much more than a canonization of Gatsby. It is an imaginative recollection that traces the movements of his knight, The Great Gatsby, down the same path Kierkegaard imaginatively follows and observes his great knight of faith in Fear and Trembling. It is the story of a hero, although tragically blinded by his own faith, a hero nonetheless who whole-heartedly finds faith in a spiritually devoid and disillusioned world, a hero who finds a way out of the crisis of modernity. 


\section{References}

Bizzell, Patricia. "Pecuniary Emulation of the Mediator in The Great Gatsby." Gatsby. Ed. Harold Bloom. New York: Chelsea House Publishers, 1991. 113-120.

Bruccoli, Matthew J. Some Sort of Epic Grandeur: The Life of F. Scott Fitzgerald. Columbia: U of South Carolina Press, 1981.

Elmore, A. E. “Nick Carraway's Self-Introduction.” Fitzgerald/Hemingway Annual. Ed. Matthew J. Bruccoli. Washington, D.C.: NCR Microcard Editions, 1971.

Fitzgerald, F. Scott. The Great Gatsby. New York: Simon \& Schuster, 1925.

Howard V. Hong and Edna H. Hong Kierkegaard Library. 2003. St. Olaf's College. 28 Mar. 2004 $<\underline{\text { http://www.stolaf.edu/collections/kierkegaard/aboutkierkegaard.html }>}$.

Kierkegaard, Soren. Either/Or. Ed. Steven L. Ross. Trans. George L. Stengren. New York: Harper \& Row, 1986.

---. Fear and Trembling/Repetition. Ed. and trans. Howard V. and Edna H. Hong. New Jersey: Princeton UP, 1983.

---. Selections from the Writings of Kierkegaard. Trans. Lee Milton Hollander. $U$ of Texas Bulletin 2326 (8 Jul. 1923). 28 Mar. 2004 $<\underline{\text { http://www.ccel.org/k/kierkegaard/selections/home.html }}$.

Lehan, Richard. The Great Gatsby: The Limits of Wonder. Boston: Twayne Publishers, 1990. 
Lewis, Roger. "Money, Love, and Aspiration in The Great Gatsby." New Essays on The Great Gatsby. Ed. Matthew J. Bruccoli. New York: Cambridge UP, 1985. 41-57. Lynn, David H. "Within and Without: Nick Carraway." Gatsby. Ed. Harold Bloom. New York: Chelsea House Publishers, 1991. 178-188.

Mallios, Peter. "Undiscovering the Country: Conrad, Fitzgerald, and Meta-National Form.” Modern Fiction Studies 47.2 (2001): 356-90.

Marino, Gordon. “About Soren Kierkegaard: Biography and Significance.” Howard V. Hong and Edna H. Hong Kierkegaard Library. Northfield: St. Olaf's College, 28 Mar. $2004<$ http://www.stolaf.edu/collections/kierkegaard/>.

Minter, David L. "Dream, Design, and Interpretation in The Great Gatsby." Twentieth Century Interpretations of The Great Gatsby A Collection of Critical Essays. Ed. Ernest H. Lockridge. Englewood Cliffs, New Jersey: Prentice Hall, Inc. 82-9. Parker, David. "Two Versions of the Hero." Modern Critical Interpretations: F. Scott Fitzgerald's The Great Gatsby. Ed. Harold Bloom. New York: Chelsea House Publ., 1986. 29-44.

Robertson, J.G. “Soren Kierkegaard.” Modern Language Review 9 (1914): 500.

Stallman, R.W. "Gatsby and the Hole in Time." Gatsby. Ed. Harold Bloom. New York: Chelsea House Publishers, 1991. 55-63.

Swenson, David F. “Soren Kierkegaard.” Scandinavian Studies and Notes 6 (Feb. 1920 Aug. 1921): 1.

---. Rev. of "Selections from the Writings of Kierkegaard" by Lee M. Hollander. Scandinavian Studies and Notes 8 (Feb. 1924 - Nov. 1925): 61. 
---. “The Anti-Intellectualism of Kierkegaard.” The Philosophical Review, 25.4 (Jul. 1916): 567-586.

Town, Caren J. “'Uncommunicable Forever:' Nick's Dilemma in The Great Gatsby.” Texas Studies in Literature and Language 31.4 (1989): 497-509. 


\section{Bibliography}

Berman, Ronald. The Great Gatsby and Fitzgerald's World of Ideas. Tuscaloosa: U of Alabama Press, 1997.

Bredvold, Louis I. Rev. of "Selections from the Writings of Kierkegaard" by Soren Kierkegaard. Trans. L.M. Hollander. Journal of English and Germanic Philology 24 (1925): 160.

Donaldson, Scott. "The Trouble with Nick." Critical Essays on F. Scott Fitzgerald's The Great Gatsby. Boston: G.K. Hall \& Co., 1984.

Gunn, Giles. "F. Scott Fitzgerald's Gatsby and the Imagination of Wonder." Critical Essays on F. Scott Fitzgerald's The Great Gatsby. Boston: G.K. Hall \& Co., 1984.

Hanzo, Thomas A. "The Theme and the Narrator of The Great Gatsby." Twentieth Century Interpretations of The Great Gatsby A Collection of Critical Essays. Ed. Ernest H. Lockridge. Englewood Cliffs, New Jersey: Prentice Hall, Inc. 61-9.

Lynn, David H. The Hero's Tale: Narrators in the Early Modern Novel. New York: St. Martin's Press, 1989

Matterson, Stephen. The Great Gatsby. London: Macmillan Education, Ltd., 1990. Monteiro, George. “Carraway’s Complaint.” Journal of Modern Literature 24.1 (2000): $161-71$. 
Nehaus, Ron. "Gatsby and the Failure of the Omniscient 'I."” The Great Gatsby: Modern Critical Interpretations. Ed. Harold Bloom. New York: Chelsea House Publ., 1986.

Ylvisaker, N. M. Rev. of "Søren Kierkegaard. Collected Works” by Soren Kierkegaard. Scandinavian Studies and Notes 8 (Feb. 1924 - Nov. 1925): 226. 